\title{
KAJIAN EKSTRAKSI GELATIN DARI TULANG IKAN MUJAIR (Oreochromis mossambicus)
}

\author{
[Studies on Extracting Gelatin From Fish Bones Tilapia (Oreochromis mossambicus)] \\ Darwin $^{1^{*}}$, Ahmad Ridhay ${ }^{1}$, Jaya Hardi ${ }^{1}$ \\ ${ }^{1}$ Jurusan Kimia Fakultas MIPA, Universitas Tadulako \\ J. Soekarno Hatta Km.9, Kampus Bumi Tadulako Tondo Palu, Telp. 0451- 422611 \\ *)Coresponding author: charlesdarwin459@gmail.com
}

Diterima 30 Oktober 2017, Disetujui 5 Januari 2018

\begin{abstract}
This study aims to determine the effect of immersion time and the ratio between the weight of tilapia fish bones to the volume of citric acid $9 \%(\mathrm{w} / \mathrm{v})$ to produce gelatin with the highest yield and the best quality. This study was conducted using a completely randomized design (CRD) with 5 level of contact time, namely $24,36,48,60$, and 72 hours and 5 level weight ratio of bone tilapia fish: citric acid of $1: 2,1: 3,1: 4,1: 5$ and $1: 6$. Determination of the influence of immersion time and ratios were calculated using weighting based on the statistical test using five test parameter: yield, ash content, water content, viscosity and gel strength. The results showed that the effect of soaking time using the 5 highest parameter was 36 hours and the ratio of $1: 6$, with a yield of $9.439 \%$, ash content of $2.8 \%$, $5.81 \%$ moisture content, viscosity $5.24 \mathrm{cP}$, and best strength gel of $38.1 \mathrm{~mm} / \mathrm{kg} . \mathrm{s}$
\end{abstract}

Keywords: Gelatin, tilapia fish bones, citric acid, viscosity, gel strength.

\begin{abstract}
ABSTRAK
Penelitian ini bertujuan untuk mengetahui pengaruh waktu perendaman dan rasio antara berat tulang ikan mujair terhadap volume asam sitrat $9 \%(\mathrm{~b} / \mathrm{v})$ dalam menghasilkan gelatin dengan rendemen tertinggi dan mutu terbaik. Penelitian ini dilakukan menggunakan rancangan acak lengkap (RAL) dengan 5 taraf waktu kontak yaitu 24, 36, 48, 60, dan 72 jam dan 5 taraf rasio berat tulang ikan mujair: asam sitrat 1:2, 1:3, 1:4, 1:5 dan 1:6. Penentuan pengaruh waktu perendaman dan rasio dilakukan dengan menggunakan metode pembobotan berdasarkan hasil uji statistik dengan menggunakan 5 parameter pengujian yakni rendemen, kadar abu, kadar air, viskositas, dan kekuatan gel. Dari hasil penelitian menunjukkan bahwa pengaruh waktu perendaman dengan menggunakan 5 parameter tertinggi adalah 36 jam dan rasio adalah 1:6, dengan rendemen 9,439\%, kadar abu 2,8\%, kadar air $5,81 \%$, viskositas $5,24 \mathrm{cP}$, dan kekuatan gel terbaik $38,1 \mathrm{~mm} / \mathrm{kg} . \mathrm{s}$
\end{abstract}

Kata kunci : Gelatin, tulang ikan mujair, asam sitrat, viskositas, kekuatan gel . 


\section{LATAR BELAKANG}

Gelatin adalah senyawa makromolekul dari golongan protein yang dapat diperoleh dari hidrolisis senyawa kolagen yang berasal dari jaringan hewan, seperti tulang, kulit, dan tendon. Senyawa ini banyak dimanfaatkan pada industri pangan dan nonpangan (Fardiaz, 1989). Pada industri pangan, gelatin dimanfaatkan stabilizer, gelling agent, perekat, viscosity agent, binder agent, emulsifier, pengental, whipping agent, dan finning agent (Poppe, 1992). Sementara itu, pada industi nonpangan umumnya digunakan sebagai bahan mikroenkapsulasi, pengikat tablet, pengikat bahan peka cahaya, pengemulsi pada produk-produk kosmetik, seperti sabun, shampo, krim pelindung sinar matahari, cat kuku, dan lipstik (Hermanianto, 2004).

Produksi gelatin di dunia sebagian besar menggunakan bahan baku bahan baku kulit babi dengan persentase 45,80\% sebagaiman data Gelatin Manufacture Europe (2006). Sementara itu, gelatin yang diproduksi dari kulit dan tulang sapi, masing-masing hanya berpresentase pada $28,40 \%$ dan 24,20\%. Permasalahan mendasar bagi warga Indonesia yang memiliki keberagaman agama adalah tidak jelasnya bahan dasar pembuatan gelatin komersial. Bagi pemeluk agama islam gelatin yang berasal dari kulit babi haram dikonsumsi, sedangkan pemeluk agama hindu tidak menkonsumsi gelatin dari kulit atau tulang sapi. Selain faktor religious tersebut, terdapat pula kekhawatiran pada faktor kesehatan, seperti penyakit sapi gila dan penyakit mulut dan kuku pada sapi yang dikhawatirkan akan menjadi masalah bagi konsumen (Peranginangin et al., 2005). Oleh karenanya, diperlukan pengembangan produksi gelatin dari sumber lainnya yang memiliki potensi besar, salah satunya dari tulang dan kulit ikan.

Tulang ikan dapat menjadi sumber gelatin karena mengandung kolagen sekitar 18,6 \% dari 19,86 \% unsur organik protein kompleks yang merupakan bahan awal pembuatan gelatin (Eastoe, 1977). Salah satu ikan yang berpotensi digunakan sebagai bahan baku pembuatan gelatin yaitu ikan mujair karena memiliki tulang yang lebih banyak dibandingkan ikan air tawar lainnya. Teknik isolasi gelatin dapat menggunakan metode asam (tipe A) dan basa (tipe B). Said et al. (2011) melaporkan bahwa penggunaan metode asam lebih baik ketimbang metode basa karena metode asam hanya memerlukan waktu perendaman yang relatif singkat sekitar 3-4 minggu untuk dapat memutus ikatan hidrogen pada struktur kolagen dibandingkan metode basa yang membutuhkan waktu 3 bulan. Selain itu, menurut Yang et al. (2008), pada proses pengolahan dengan larutan asam menghasilkan kekuatan gel, nanostruktur, dan tekstur yang lebih baik dibandingkan menggunakan larutan basa.

Hasil penelitian Janah (2008) pada pencarian pelarut terbaik untuk ekstraksi gelatin dengan menggunakan tulang 
bandeng sebagai bahan baku dan pelarut asam yaitu $\mathrm{HCl} 5 \%$ dan $\mathrm{C}_{3} \mathrm{H}_{5} \mathrm{O}(\mathrm{COOH})_{3}$ $5 \%$ dan pelarut basa yakni $\mathrm{Ca}(\mathrm{OH})_{2} 10 \%$. Ekstrak gelatin terbaik dihasilkan dari perendaman dengan pelarut asam sitrat selama 6 hari dengan kadar protein 4,6909 $\%$, kekuatan gel 10,5 mm/g.dt dan viskositas 2,2661 cP. Ridhay dkk (2016) juga melaporkan bahwa penggunaan asam sitrat $5 \%$ dapat menghasilkan kekuatan gel gelatin yang tinggi $(47,6 \mathrm{~mm} / \mathrm{kg} . \mathrm{s})$ atau lebih tinggi dibandingkan gelatin komersial (45,5 mm/kg.s). Sementara itu, pengaruh lama perendaman berpengaruh positif terhadap jumlah gelatin yang dihasilkan Fatimah (2008). Hal ini dikarenakan waktu kontak antara asam dengan tulang semakin lama sehingga memiliki kesempatan lebih besar untuk saling berinteraksi. Selain lama perendaman rasio antara berat sampel dengan volume larutan pelarut diduga juga berpengaruh terhadap kuantitas dan kualitas gelatin. Berdasarkan hal di atas perlu dilakukan variasi rasio asam sitrat dan lama perendaman untuk mendapatkan gelatin terbaik.

\section{METODE PENELITIAN}

\section{Bahan dan Peralatan}

Bahan dasar yang digunakan dalam penelitian ini adalah tulang ikan mujair. Bahan - bahan lain yang diperlukan antara lain: Asam sitrat 9\%, dan aquadest.

Peralatan yang digunakan : Penangas Shaker, gunting, batang pengaduk, neraca analitik, rotari vakum evaporator, viskometer ostwald, Penetrometer, cawan porselen, desikator, magnetik stirer, $\mathrm{pH}$ meter, blender, alat destilasi, oven, gelas ukur dan alat gelas yang umum digunakan dilaboratorium kimia.

\section{Rancangan Penelitian}

Rancangan yang digunakan adalah rancangan acak lengkap (RAL) yang terdiri dari dua faktor yaitu variasi waktu perendaman (24 jam, 36 jam, 48 jam, 60 jam, 72 jam) dan rasio berat tulang dengan volume asam $(1: 2,1: 3,1: 4,1: 5,1: 6)$ Perlakuan ini diulang sebanyak dua kali sehingga diperoleh 20 unit percobaan.

\section{Prosedur Penelitian}

Produksi gelatin dilakukan menggunakan metode Junianto dkk (2006) dan Ridhay dkk (2016) dengan beberapa modifikasi.

\section{Preparasi Sampel}

Ikan mujair segar diambil tulangnya kemudian dibersihkan dari daging dan kulitnya. Kemudian tulang dicuci dengan air mengalir hingga bersih.

\section{Degresing}

Tulang ikan yang telah disiapkan dipisahkan dari daging dan kulitnya, lalu dibersihkan dengan air. Kemudian tulang ikan didegreasing yaitu direndam dalam air pada suhu $70^{\circ} \mathrm{C}-80^{\circ} \mathrm{C}$ selama 10 menit sambil diaduk-aduk. Tulang selanjutnya disimpan di dalam loyang dan dibersikan dari sisa lemak yang masih menempel 
dengan air. Tulang ditiriskan dengan kain saring dan dibiarkan kering dengan cara diangin-anginkan dan selanjutnya dipotong kecil-kecil (1-2 cm).

\section{Demineralisasi dan Ekstraksi}

Tulang ikan berukuran 1-2 cm direndam dalam larutan asam sitrat 9\% dengan rasio tulang dalam laruatan asam 1:3 (b/v) selama 24 jam, 36 jam, 48 jam, 60 jam dan 72 jam. Setelah itu tulang dicuci dengan air mengalir sampai $\mathrm{pH}$-nya netral Tulang ber-pH netral tersebut diekstraksi dengan aquades dengan rasio 1:3 (b/v) dalam water bath shaker pada suhu $70^{\circ}-$ $80^{\circ} \mathrm{C}$ selama 6 jam yang kemudian disaring dan dipekatkan. Cairan pekat gelatin yang diperoleh itu dituang ke dalam wadah dan disimpan dalam oven pada suhu $50^{\circ} \mathrm{C}$ selama 24 jam. Gelatin kering yang dihasilkan kemudian ditentukan rendemen dan dilakukan uji karakterisasi, meliputi kadar air, kadar abu, viskositas, dan kekuatan gel.

\section{HASIL DAN PEMBAHASAN}

\section{Gelatin Tulang Ikan Mujair pada Berbagai Waktu Perendaman}

\section{Rendemen Gelatin}

Penentuan rendemen gelatin bertujuan untuk melihat seberapa efektif dan efisien proses ekstraksi hingga pembuatan gelatin dilakukan (Fahrul, 2005). Tingginya nilai rendemen akan menunjukkan tingkat efisiensi yang tinggi selama proses pembuatan. Persentase berat dari denaturasi kolagen adalah gambaran dari rendemen atau kuantitas gelatin.

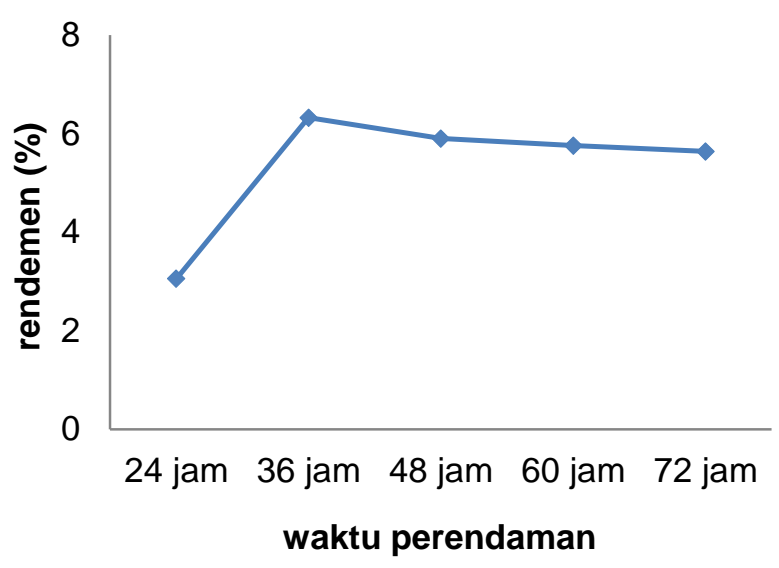

Gambar 1 Grafik hubungan lama waktu perendaman dengan rendemen

Rendemen gelatin diperoleh akan semakin tinggi seiring dengan semakin lamanya waktu perendaman (Gambar 1). Hal ini dikarenakan semakin lama waktu kontak maka molekul asam sitrat terhadap tulang semakin meningkat, sehingga kolagen yang terlarut dalam asam semakin banyak. Menurut Munda (2013), lamanya waktu perendaman akan menyebabkan jaringan fibril pada kolagen akan rusak sehingga jumlah komponen kolagen yang terlarut dalam asam lebih tinggi dan akan mengakibatkan penurunan nilai rendemen gelatin.

Hasil penelitian menunjukkan ratarata rendemen yang didapatkan yakni berkisar antara 3,055\% sampai 6,319 \%, dengan 24 jam (3,055\%), 36 jam (6,319\%), 48 jam (5,897\%), 60 jam (5,755\%), dan 72 jam $(5,635 \%)$. Rata - rata rendemen tertinggi yang dihasilkan adalah pada waktu lama perendaman 36 jam yakni $(6,319 \%)$, sedangkan rendemen terkecil adalah pada waktu perendaman 24 jam. 
Hasil analislis ragam uji statistik menunjukan bahwa jika nilai $F$ hitung $>F$ tabel maka maka nilai tersebut berbeda nyata, dengan nilai tertinggi berdasarkan uji BNJ adalah 36 jam.

\section{Kadar Abu}

Abu didefiniskan sebagai zat yang tidak akan habis setelah proses pembakaran zat organik, meliputi unsurunsur anorganik atau mineral (Winarno, 1992). Oleh karenanya jumlah mineral dalam suatu bahan pangan dapat ditentukan melalui perhitungan kadar abu (Apriyantono, 1989 dan Fatimah, 2008). Kadar abu dapat menjadi salah satu indikator kemurnian dari gelatin tulang ikan mujair yang dihasilkan.

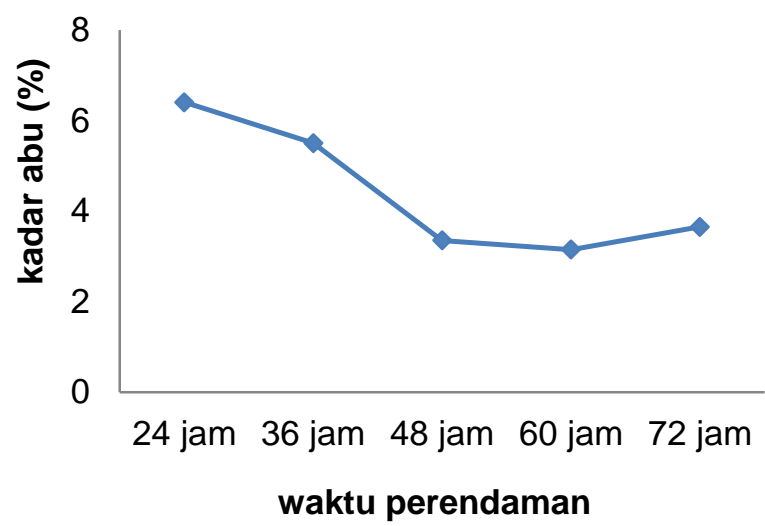

Gambar 2 Grafik hubungan lama perendaman terhadap kadar abu.

Kadar abu gelatin tulang ikan mujair yang dihasilkan semakin kecil dengan meningkatnya waktu perendaman (Gambar 2). Menurut Courts and Johns (1977) bahwa jenis asam yang digunakan dalam hidolisis kolagen akan berpengaruh terhadap jumlah dan sifat gelatin yang dihasilkan, karena setiap perbedaan waktu konsentrasi akan menyebabkan perbedaan pada jumlah garam-garam mineral yang akan dilepas, semakin lama waktu perendaman maka akan semakin banyak garam-garam mineral yang akan dilepas dari kolagen sehingga akan mengurangi dan menpengaruhi kadar abu yang dihasilkan.

Rata- rata hasil kadar abu pada lama perendaman berkisar antara 3,7 \% - 6,4, dengan lama perendaman 24 jam (6,40\%), 36 jam (5,50\%), 48 jam (3,35\%), 60 jam $(3,15 \%)$, dan 72 jam (3,65\%). Dimana kadar abu terkecil terdapat pada lama perendaman 60 jam yakni 3,15\% .Hasil tersebut telah memenuhi Standar Nasional Indonesia (SNI) yaitu maksimal 3,25\%. Hasil analisis sidik ragam ditunjukkan bahwa variasi lama perendaman berpengaruh nyata terhadap kadar abu gelatin yang dihasilkan. Berdasarkan uji lanjut BNJ perlakuan lama perendamaan 24 jam berbeda nyata dengan perlakuan lainnya.

\section{Kadar Air}

Parameter lain yang sangat penting pada produk gelatin adalah kadar air karena sangat berpengaruh pada tampilan fisik, rasa, dan masa penyimpanan dari gelatin. Air dalam gelatin dapat terikat secara kimia dan fisik ataupun dalam bentuk bebas. Kisaran kadar air gelatin hasil ekstraksi dari tulang ikan mujair adalah 6,35 - 9,45 \%. Nilai kadar air tersebut masih berada dalam kisaran kadar air yang diperkenankan oleh Standar 
Nasional Indonesia (SNI) No. 3735 tahun 1995 untuk produk gelatin yaitu maksimum $16 \%$.

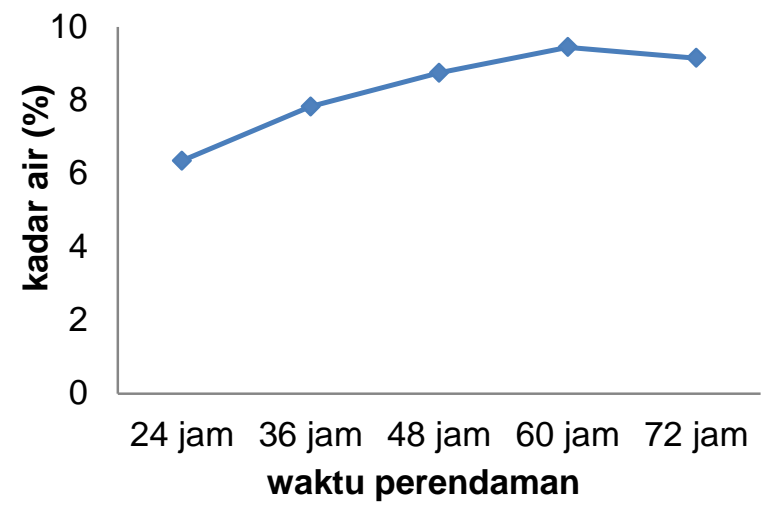

Gambar 3 Grafik hubungan waktu perendaman terhadap kadar air.

Grafik hubungan antara lama waktu perendaman menunjukkan bahwa semakin lama waktu perendaman maka kadar air semakin meningkat (Gambar 3). Hal ini diduga karena semakin lama waktu perendaman, maka air yang terikat dalam larutan gelatin semakin banyak atau daya tarik air dengan senyawa gelatin sangat kuat, kekuatan daya tarik air inilah yang menyebabkan air sulit keluar saat diuapkan. Hasil analisis sidik ragam, lama perendaman berpengaruh terhadap kadar air gelatin, dimana hasil uji BNJ menujukkan lama perendaman 24 jam berbeda sangat nyata dengan lama perendaman lainnya.

\section{Viskositas}

Mutu gelatin juga dapat ditinjau dari nilai viskositasnya. Viskositas gelatin dipengaruhi oleh berat molekul dan distribusi molekul, dilain pihak berat molekul gelatin sendiri berhubungan dengan panjang rantai asam aminonya.
Nilai viskositas gelatin akan semakin tinggi jika rantai asam aminonya semakin panjang. Berdasarkan hasil analisis, nilai viskositas gelatin tulang ikan mujair yang dihasilkan berkisar antara 2,68- 4,74 centipoise (cPs). Nilai viskositas tertinggi pada perlakuan lama perendaman 60 jam, yaitu sebesar 4,74 cP, sedangkan nilai viskositas terendah diperoleh gelatin dengan perlakuan lama perendaman 24 jam, yaitu sebesar 2,68 cPs (Gambar 4).

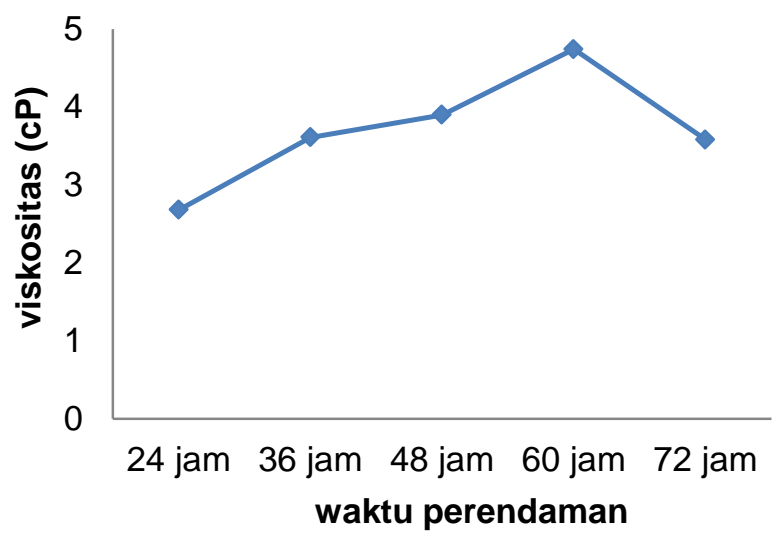

Gambar 4 Grafik hubungan antara waktu perendaman terhadap viskositas

Semakin lama waktu perendaman maka nilai viskositas gelaitn semakin meningkat, karena semakin lama waktu perendaman maka waktu kontak antara asam dengan tulang semakin meningkat sehingga kesempatan penguraian rantai asam amino semakin meningkat. Hasil analisis sidik ragam menunjukkan lama perendaman berpengaruh nyata terhadap viskosistas. Viskositas pada waktu perendaman 24 jam berbeda sangat nyata dengan 60 jam, namun 24 jam berbeda tidak nyata dengan lama perendaman 36 jam, 48 jam, dan 72 jam. Adanya 
perbedaan viskositas antara setiap perlakuan disebabkan karena perbedaan kadar abu dari gelatin tulang ikan mujair.

\section{Kekuatan Gel}

Salah satu fisik gelatin yang sangat penting adalah kekuatan gel (Rusli, 2004), karena gelatin harus memiliki sifat berupa dapat berubah wujud dari cairan menjadi padatan atau mengubah sol menjadi gel yang bersifat reversible. Molekul-molekul gelatin yang dipanaskan dapat mengembang sehingga terbentuk gel. (Stainsby, 1977).

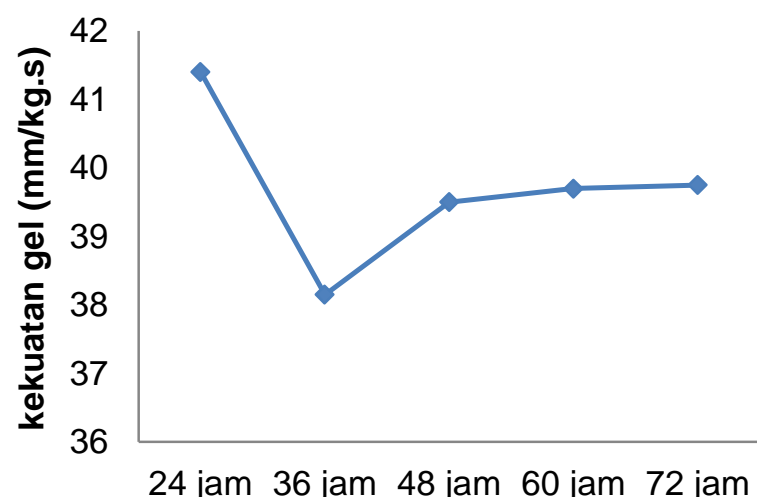

waktu perendaman

Gambar 5 Grafik hubungan antara waktu perendaman dengan kekuatan gel

Pengukuran kekuatan gel ini dilakukan menggunakan alat yang disebut penetrometer, dengan cara pengujian penetrasi yaitu waktu yang dibutuhkan untuk penekanan terhadap sampel yang mengandung gelatin $5 \%$. Kekuatan gel dengan nilai terendah adalah yang memiliki kualitas gel terbaik, karena pada metode ini lamanya waktu penetrasi menjadi acuan dalam penentuan nilai kekutan gel sampel. Semakin lama waktu penetrasi maka angka yang diperoleh semakin kecil, begitu juga sebaliknya (Fatimah, 2008).
Data hasil penelitian (Gambar 5) menunjukkan bahwa kekuatan gel rata-rata gelatin dari tulang ikan mujair berkisar antara $41,4 \quad \mathrm{~mm} / \mathrm{Kg} . \mathrm{s}$ sampai 39,75 $\mathrm{mm} / \mathrm{Kg}$.s. Nilai gelatin terbaik berada pada waktu perendaman 36 jam yakni 39,50 $\mathrm{mm} / \mathrm{Kg}$.s sedangkan kekuatan gel terendah berada pada waktu perendaman 24 jam yakni 41,40 mm/Kg.s. Kekuatan gel gelatin tulang ikan mujair hasil penelitian ini masih di bawah kekuatan gel komersial namun tidak berbeda secara signifikan dimana nilai kekuatan gel pada gelatin komersial mencapai 37,1 mm/Kg.s. Tingginya kekuatan gel berkaitan dengan panjang rantai asam amino yang panjang akan menghasilkan kekuatan gel yang besar pula. Pada hidrolisis yang optimal akan menghasilkan rantai asam amino yang panjang pada saat konversi kolagen menjadi gelatin sehingga dihasilkan kekuatan gel yang tinggi pula (Astawan, 2002).

Hasil sidik ragam menunjukkan bahwa lama perendaman berpengaruh nyata terhadap kekuatan gel dari gelatin hasil penelitian, dimana hasil uji BNJ diperoleh bahwa pada lama perendaman 24 jam berbeda sangat nyata terhadap 36 jam, 48 jam, 60 jam, dan 72 jam, namun pada waktu 48 jam, 60 jam serta 72 jam berbeda tidak nyata. Adanya perbedaan nilai kekuatan gel diantara perlakuan ini disebabkan pada setiap penambahan waktu terjadi penurunan kadar protein, Lestari (2005) menyatakan bahwa perbedaan kekuatan gel diantara 
perlakuan diduga disebabkan karena perbedaan komponen abu. Keberadaan mineral dalam jumlah tinggi dapat mempengaruhi kekuatan gel produk gelatin.

Penentuan perlakuan terbaik dilakukan dengan menggunakan pembobotan statistik sederhana dengan beberapa parameter yakni rendemen, kadar abu, kadar air, viskositas dan kekuatan gel. Berdasarkan parameter tersebut diperoleh waktu perendaman terbaik pada pembuatan gelatin tulang ikan mujair adalah 36 jam (Tabel 1).

Tabel 1 Hasil analisis parameter gelatin pada berbagai waktu perendaman

\begin{tabular}{ccccccc}
\hline \multirow{2}{*}{ Parameter } & \multicolumn{5}{c}{ Waktu Perendaman (jam) } & \multirow{2}{*}{ Komersil } \\
\cline { 2 - 6 } & $\mathbf{2 4}$ & $\mathbf{3 6}$ & $\mathbf{4 8}$ & $\mathbf{6 0}$ & $\mathbf{7 2}$ & \\
\hline Rendemen (\%) & 3,055 & 6,319 & 5,897 & 5,733 & 5,635 & \\
Kadar abu (\%) & 6,4 & 5,5 & 3,4 & 3,2 & 3,7 & 0,75 \\
Kadar air (\%) & 6,35 & 7,83 & 8,75 & 9,45 & 9,15 & 11,70 \\
Viskositas (\%) & 2,68 & 3,62 & 3,90 & 4,74 & 3,58 & 5,04 \\
Kekauatan gel (mm/kg.s) & 41,40 & 38,15 & 39,50 & 39,70 & 39,75 & 37,1 \\
\hline
\end{tabular}

\section{Rasio Tulang Ikan Mujair Terhadap Volume Asam}

\section{Rendemen Gelatin}

Berdasarkan grafik pada Gambar 6 terlihat bahwa semakin tinggi rasio tulang dan pelarut maka rendemen yang dihasilkan makin tinggi pula. Hal tersebut dikarenakan asam yang digunakan akan bereaksi dengan kalsium pada tulang sehingga garam kalsium pada tulang akan terlarut Huda et al. (2013).

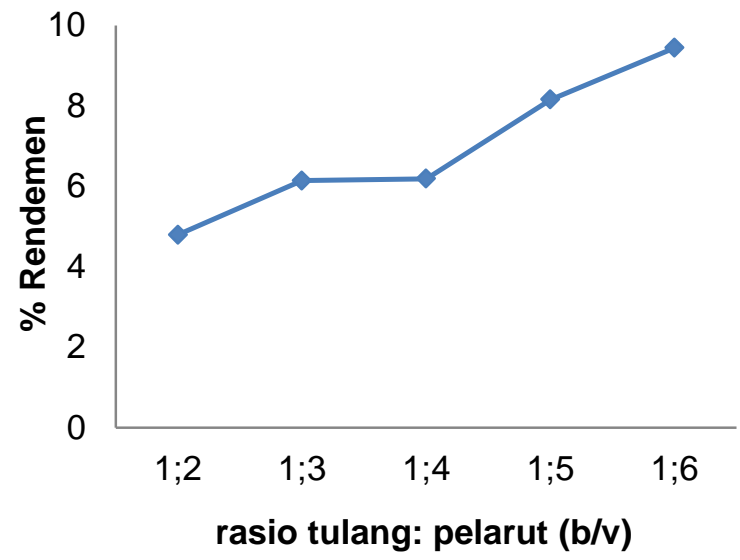

Gambar 6 Grafik hubungan antara rasio tulang terhadap pelarut dengan rendemen
Rendemen yang diperoleh berkisar antara 4,789\% - 9,439. Nilai rendemen pada rasio $1: 2,1: 3,1: 4,1: 5$, dan $1: 6$ masing-masing 4,789\%, 6,141\%, 6,185\%, $8,153 \%$, dan 9,439\%. Hasil analislis sidik ragam menujukan bahwa perlakuan rasio berpengarh nyata terhadap rendemen, dimana hasil uji lanjut BNJ menunjukkan rasio $1: 2,1: 3,1: 4,1: 5$, dan 1:6 berbeda nyata tetapi rasio $1: 3$ dan 1:4 berbeda tidak nyata.

\section{Kadar Abu}

Gelatin dengan kadar abu yang rendah sangat baik dimanfaatkan dalam pengolahan pangan. Kadar abu gelatin semakin rendah sering dengan meningkatnya rasio tulang ikan terhadap pelarut. Hal ini disebabkan adanya perbedaan jumlah asam, dimana semakin tinggi jumlah asam maka akan semakin banyak mineral-mineral yang berupa abu 
yang akan diikat, sehingga berpengaruh positif terhadap kadar abu dalam gelatin.

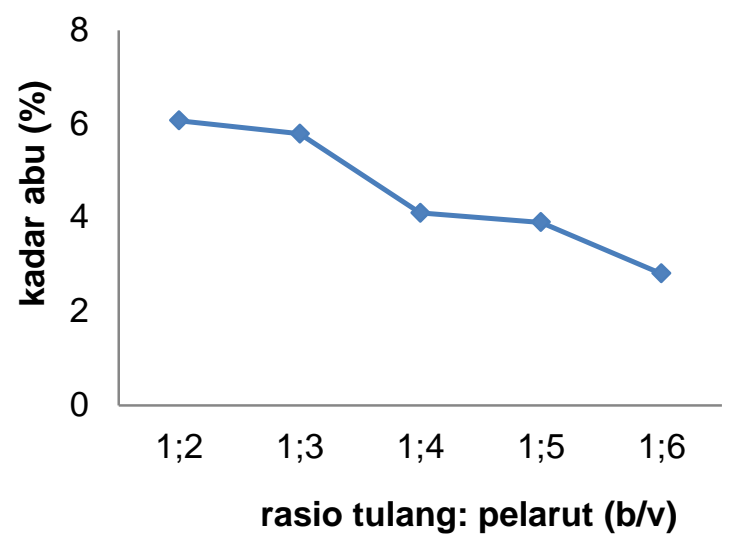

Gambar 7 Grafik hubungan antara rasio tulang terhadap pelarut dengan kadar abu

Kadar abu gelatin berkisar antara 6,07\% sampai 2,81 \% (Gambar 7), dimana kadar abu terendah diperoleh pada 1:6 $(2,82 \%)$. Hasil perlakuan ini masih jauh lebih tinggi jika di bandingkan dengan kadar abu gelatin komersial, yaitu 0,75 \%, namun demikian rasio 1:6 telah memenuhi Standar Nasional Indonesia (SNI), yaitu maksimal 3,25\%.

\section{Kadar Air}

Hasil rata-rata kadar air gelatin produk tulang ikan mujair pada berbagai rasio dapat dilihat pada grafik berikut :

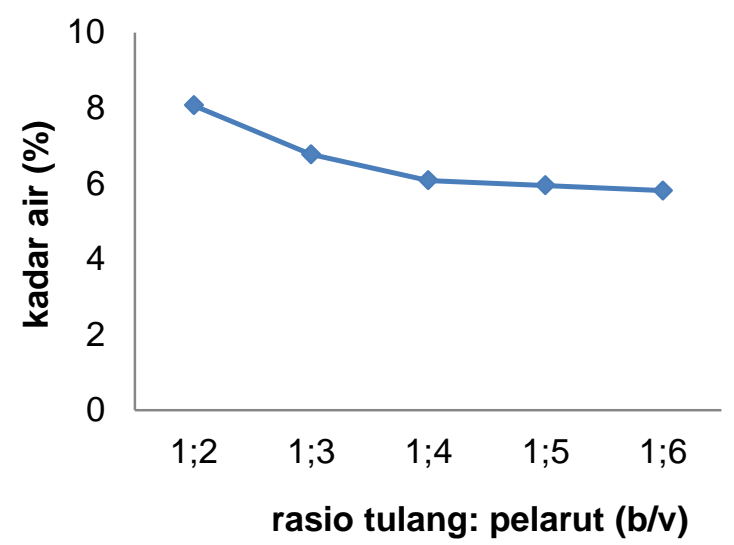

Gambar 8 Grafik hubungan antara rasio tulang terhadap pelarut dengan kadar air
Grafik hubungan antara rasio tulang terhadap volume larutan asam dengan kadar air menunjukkan bahwa semakin tinggi volume asam maka kadar air yang dihasilkan cenderung menurun (Gambar 8). Kadar air pada rasio 1:2 (8,07\%), 1:3 $(6,77 \%), 1: 4(6,08 \%), 1: 5$ (5,95\%), dan 1:6 (5,81 \%) masih lebih baik jika dibandingkan dengan gelatin komersial yakni $11,695 \%$ dan juga telah memenuhi standar kadar air yang diajukan SNI, yakni $16 \%$. Hasil uji statistikmenunjukkan bahwa rasio $1: 3$ dan $1: 4$ berbeda tidak nyata tetapi berbeda nyata terhadap perlakuan lainnya.

\section{Viskositas}

Gealtin tulang ikan mujair memiliki viskositas tertinggi pada rasio 1:4, yaitu 5,24 cPs, sedangkan viskositas terendah yaitu pada variasi rasio $1: 2$,yaitu 2,15 cPs (Gambar 9).

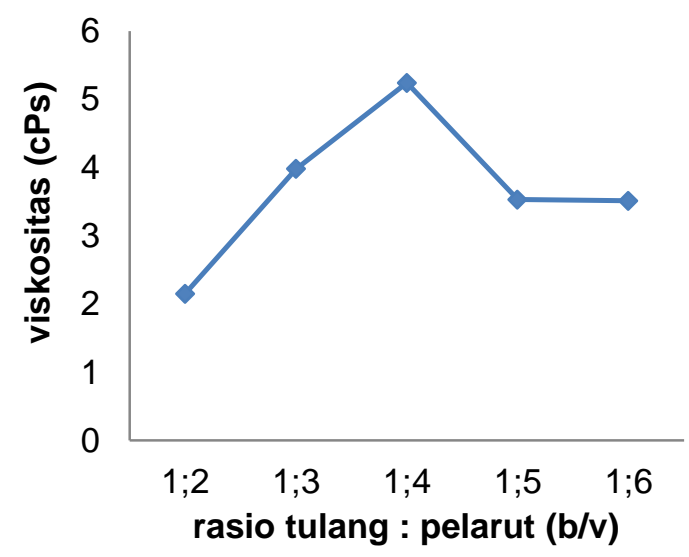

Gambar 9 Grafik hubungan antara rasio tulang terhadap pelarut dengan viskositas

Semakin tinggi volume asam sitrat maka viskositas semakin meningkat hingga pada penggunaan rasio 1:5 dan selanjutnya viskositas cenderung menurun. Menurut Pelu (1998) viskositas gelatin 
salah satunya dipengaruhi oleh konsentrasi asam, apabila konsentrasi larutan asam meningkat akan menyebabkan kation yang terperangkap dalam ossein akan semakin banyak, sehingga $\mathrm{pH}$ yang terukur semakin rendah. Hasil analisis sidik ragam, rasio berpengaruh nyata terhadap viskositas dan pada uji BNJ, rasio 1:3 berbeda sangat nyata terhadap 1:2 dan 1:4 tetapi berbeda tidak nyata dengan $1: 5$ serta $1: 6$, namun hasil tersebut sudah memenuhi standar nasinal indonesia (SNI) dimana maksimum viskositas yang disajikan yakni 1,5 cPs sampai $7 \mathrm{cPs}$.

\section{Kekuatan Gel}

Rasio 1:2 menghasilkan kekuatan gel tertinggi $(41,3 \quad \mathrm{~mm} / \mathrm{kg} . \mathrm{s})$, sedangkan kekuatan gel terendah yaitu pada variasi rasio 1:6 (38,1 mm/kg.s) (Gambar 10). Kekuatan gel yang dihasilkan ini berkisar sekitar 41,3 mm/Kg.s sampai 38,1 $\mathrm{mm} / \mathrm{Kg}$.s. Hasil kekuatan gel rata-rata dari berbagai macam rasio, yakni 1:2 (41,3 mm/Kg.s), $1: 3 \quad$ (41 mm/Kg.s), $1: 4 \quad(39,1$ mm/Kg.s), $1: 5$ (38,5 mm/Kg.s), dan 1:6
(38,1 mm/kg.s) masih lebih baik jika di bandingkan dengan gelatin komersial yaitu $37,1 \mathrm{~mm} / \mathrm{kg} . \mathrm{s}$. Hal ini disebabkan jumlah kadar abu pada gelatin ini masih terbilang tinggi bila dibandingkan dengan gelatin komersial. Tingginya kadar abu dapat menyebakan turunnya nilai kekuatan gel dari gelatin. Hasil analisis sidik ragam dan uji BNJ menunjukkan bahwa pada berbagai rasio berbeda tidak nyata terhadap kekuatan gel yang dihasilkan. Berdasarkan seluruh parameter diperoleh rasio terbaik pembuatan gelatin tulang ikan mujair adalah 1:6

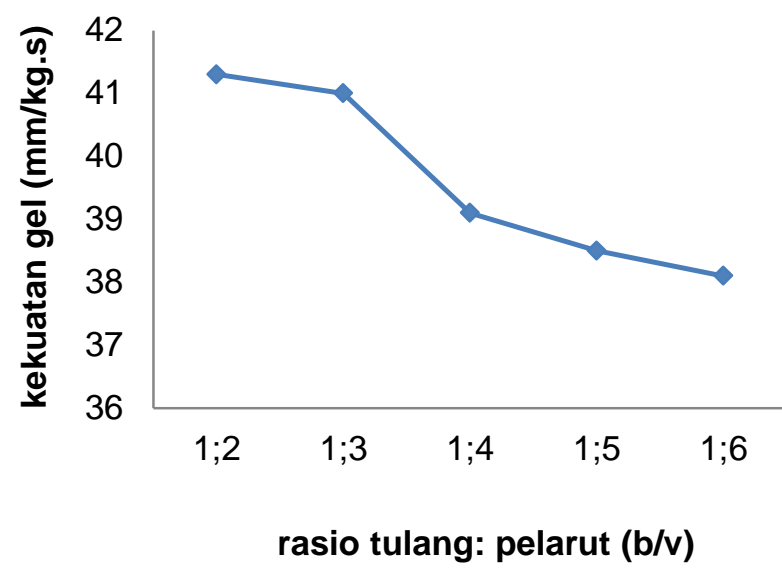

Gambar 10 Grafik hubungan antara rasio tulang terhadap pelarut dengan kekuatan gel

Tabel 2 Hasil analisis parameter gelatin produk tulang ikan mujair variasi rasio

\begin{tabular}{cccccc|c}
\hline \multirow{2}{*}{ Parameter } & \multicolumn{5}{c|}{ Waktu Perendaman (jam) } & \multirow{2}{*}{ Komersil } \\
\cline { 2 - 5 } & $\mathbf{1 : 2}$ & $\mathbf{1 : 3}$ & $\mathbf{1 : 4}$ & $\mathbf{1 : 4}$ & $\mathbf{1 : 5}$ & \\
\hline Rendemen (\%) & 4,788 & 6,141 & 6,185 & 8,153 & 9,439 & \\
Kadar abu (\%) & 6,1 & 5,8 & 4,1 & 3,9 & 2,8 & 0,75 \\
Kadar air (\%) & 8,07 & 6,77 & 6,08 & 5,95 & 5,81 & 11,70 \\
Viskositas (\%) & 2,15 & 3,98 & 5,24 & 3,54 & 3,52 & 5,04 \\
Kekauatan gel & 41,3 & 41 & 39,1 & 38,5 & 38,1 & 37,1 \\
(mm/kg.s) & & & & & \\
\hline
\end{tabular}

\section{Spektrum Inframerah (IR) Gelatin}

Proses Analisis gugus fungsi berfungsi untuk mengetahui karakteristik pita serapan gelatin dengan menggunakan spektrofotometri FTIR. Analisis spektrum dipusatkan pada penentuan ada tidaknya sejumlah gugus fungsional. 


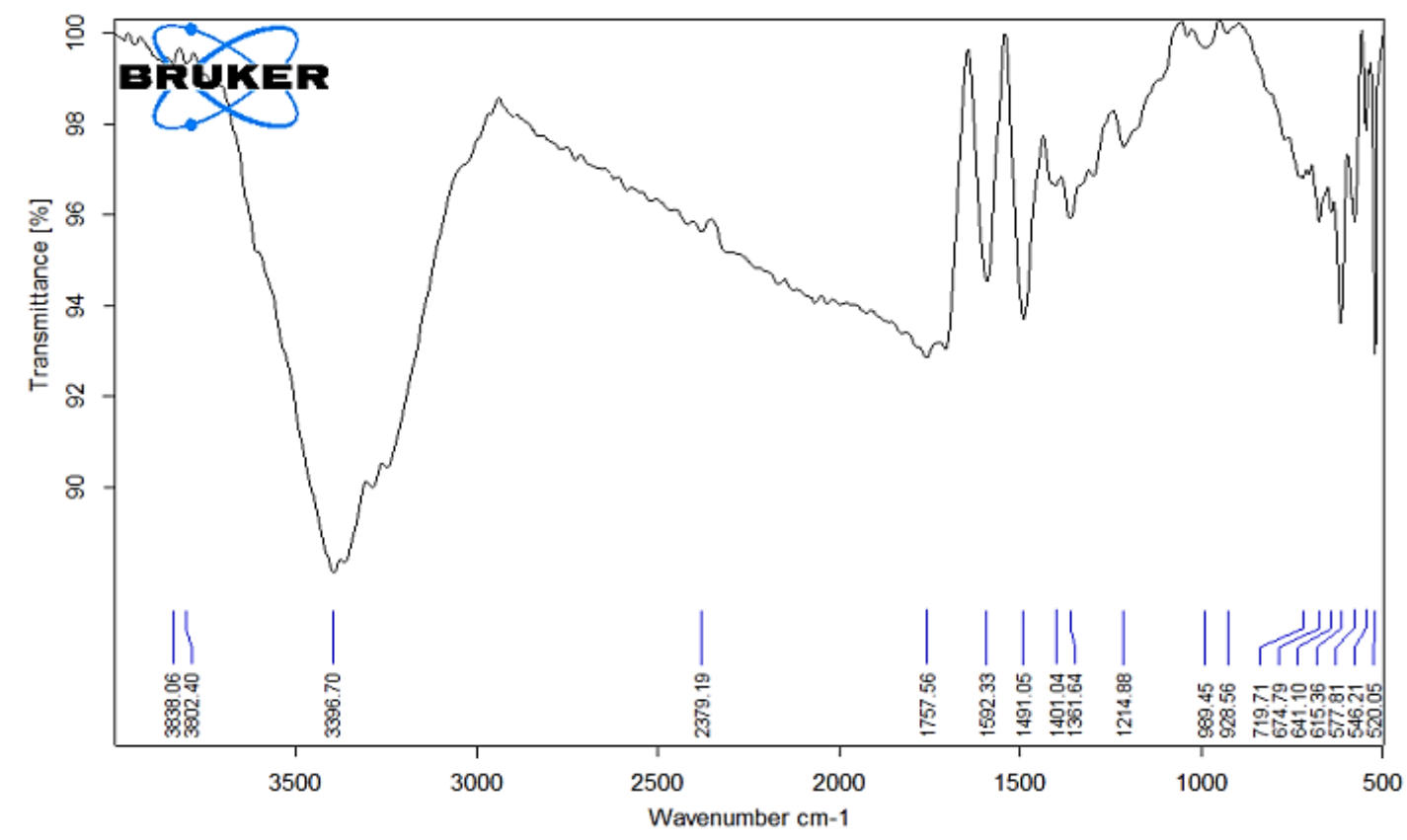

Gambar 11 Spektrum Infrared Gelatin Tulang Ikan Mujair

Spektrum IR gelatin menunjukkan adanya serapan pada bilangan gelombang $3396,70 \mathrm{~cm}^{-1}$ yang menandakan adanya vibrasi stretching gugus fungsi $\mathrm{OH}$ (Gambar 11). Menurut Fessenden (1986), gugus $-\mathrm{OH}$ terdapat antara bilangan gelombang $3000-3700 \mathrm{~cm}^{-1}$. Serapan pada panjang gelombang $2379,19 \mathrm{~cm}^{-1}$ menandakan adanya regangan $\mathrm{N}-\mathrm{H}$ dari $\mathrm{C}=\mathrm{NH}$ yang terdapat pada daerah 2700$2250 \mathrm{~cm}^{-1}$. Serapan pada panjang gelombang 1592,33 $\mathrm{cm}^{-1}$ menunjukkan adanya tekukan $\mathrm{N}-\mathrm{H}$ dari amina primer yang terdapat pada daerah $1650-1580 \mathrm{~cm}$ 1. Serapan pada panjang gelombang $1491,05 \mathrm{~cm}^{-1}, 1401,04 \mathrm{~cm}^{-1}$ dan 1361,64 $\mathrm{cm}^{-1}$ menunjukkan adanya bending $\mathrm{OH}$ yang terdapat pada daerah $1500-1300 \mathrm{~cm}^{-}$ ${ }^{1}$. Adanya gugus - $\mathrm{OH}$ dimungkinkan karena masih adanya senyawa $\mathrm{OH}$ dari air yang digunakan untuk mengekstraksi gelatin.
Serapan pada panjang gelombang 1214,88 $\mathrm{cm}^{-1}$ menunjukkan adanya deformasi $\mathrm{CH}_{2}$ yang terdapat pada daerah 1200- $1500 \mathrm{~cm}^{-}$ ${ }^{1}$, dimana daerah ini spesifik untuk gugus hidrokarbon pada senyawa asam lemak, protein, atau polisakarida.

Spektra gugus fungsi hidroksil $(\mathrm{O}-\mathrm{H})$, dan gugus amina $(\mathrm{N}-\mathrm{H})$ yang diperoleh pada penelitian ini menunjukkan gugus fungsi yang sama dengan gelatin. Menurut Marsaid (2011) gelatin seperti umumnya protein memiliki struktur yang terdiri dari karbon, hidrogen, gugus hiroksil $(\mathrm{OH})$, gugus karbonil $(\mathrm{C}=\mathrm{O})$, dan gugus amina $(\mathrm{NH})$, sehingga dapat disimpulkan bahwa senyawa yang diperoleh pada penelitian ini adalah gelatin.

\section{KESIMPULAN}

Waktu perendaman terbaik didiapatkan pada waktu 36 jam dengan rendemen 6,319\%; kadar abu 3,2\%; kadar 
air 6,35\%; viskositas 4,74 cP; dan kekuatan gel $38,15 \mathrm{~mm} / \mathrm{Kg}$.s.

Rasio terbaik antara berat tulang ikan mujair terhadap volume asam sitrat $9 \%$ yaitu 1:6 dengan rendemen 9,439\%; kadar abu 2,8\%; kadar air 5,81\%; viskositas 3,52 cP; dan kekuatan gel 38,1 mm/Kg.s.

\section{DAFTAR PUSTAKA}

Apriyantono, A., Fardiaz, D., Puspitasari, NL., Sedarnawati, Budiyanti, S. (1989). Analisis Pangan. Bogor: Institut Pertanian Bogor.

Astawan, M., Haryadi, P., Mulyani, A. (2002). Analisis Sifat Reologi Gelatin Dari Kulit Ikan Cucut. Jurnal Teknologi Dan Industri Pangan. 8 (1): 38-46.

Courts, A., Johns, P. (1977). Relationship between collagen and gelatin. Di dalam The Science and Technology of Gelatin. Ward AG dan Courts A, editors. New York: Academic Press.

Eastoe, J.E. (1977). The Chemical Examination of Gelatin. In : Ward. AG; and A.Courts, Editors. The Science and Technology of Gelatin. New York: Academic Press.

Fardiaz, D. (1989). Hidrokolid. Bogor: Pusat Antar Universitas Pangan dan Gizi IPB.

Fahrul. (2005). Kajian Ekstraksi Gelatin dari Kulit Ikan Tuna (Thunnus alalunga) dan Karakteristiknya sebagai Bahan Baku Industri Farmasi. Thesis. Bogor: Institut Pertanian Bogor.

Fatimah, D. (2008). Efektivitas Penggunaan Asam Sitrat Dalam Pembuatan Gelatin Tulang Ikan Bandeng (Chanos- Chanos forskal). Skripsi. Malang: Universitas Islam Negri Maulana Malik Ibrahim.

Fessenden, Fessenden. (1982). Kimia Organik Edisi Ketiga jilid 2. Jakarta : Erlangga.
Huda, W N., Atmaka, W., Nurhartadi, W. (2013). Kajian Karakteristik Fisik Dan Kimia Gelatin Ekstrak Tulang Kaki Ayam (Gallus galus bankiva) Dengan Variasi Lama Perendaman Dan Konsentrasi Asam. Jurnal Teknosains Pangan. 2(3): 70-75.

Hermanianto, J. (2004). Gelatin: Keajaiban dan Kehalalannya. (www.modules.php.html, diakses pada tanggal 12 September 2016).

Janah, A. (2007). Pembuatan Gelatin Halal Dari Tulang Ikan Bandeng (Chanoschanos forskal) (Sebagai Alternatif Pembuatan Gelatin Halal), Laporan Penelitian, Malang: LEMLIT UIN Malang.

Junianto, K., Haetami, Ine, M. (2006). Produksi Gelatin dari Tulang Ikan dan Pemanfaatannya sebagai Bahan Dasar Pembuatan Cangkang Kapsul. Laporan Penelitian Hibah Bersaing tahun I. Bandung: Fakultas Perikanan dan IImu Kelautan Universitas Padjajaran.

Lestari, S D. (2005). Analisis sifat fisika kimia dan rheologi gelatin kulit hiu gepeng (Alopias $\mathrm{sp}$ ) dengan penambahan MgSO4, sukrosa, dan gliserol. Skripsi. Bogor: Fakultas Perikanan dan IImu Kelautan Institut Pertanian Bogor.

Munda, M. (2013). Pengaruh Konsentrasi Asam Asetat dan Lama Demineralisasiterhadap Kuantitas dan Kualitas Gelatin Tulang Ayam. Skripsi. Makasar: Universitas Hasanudin.

Peranginangin, R., Mulyasari, A. Sari, Tazwir. (2005). Karakterisasi Mutu Gelatin Yang Diproduksi dari Tulang Ikan Patin (Pangsius hypopthalmus) Secara Ekstraksi Asam. Jurnal Penelitian Perikanan Indonesia. 11(4).

Pelu, H., Herawati, S., Chasanah, E. (1998). Ekstraksi gelatin dari kulit ikan tuna melalui proses asam. Jurnal Penelitian Perikanan Indonesia. 4(2): 6-74. 
Poppe, J. (1992). Gelatin. Di dalam A. Imeson (ed). Thickening and Gelling Agent for Food. New York: Academic Press.

Ridhay, A., Musafira, M., Nurhaeni, N., Nurakhirawati, N., \& Khasanah, N. B. (2016). Pengaruh Variasi Jenis Asam Terhadap Rendemen Gelatin Dari Tulang Ikan Cakalang (Katsuwonus pelamis). KOVALEN, 2(2).

Rusli, A. (2004). Kajian Proses Ekstraksi Gelatin dari Kulit Ikan Patin Segar. Thesis. Bogor: Sekolah Pascasarjana IPB.

Said, M.I., S Triatmojo., Y Erwanto., A. Fudholi. (2011). Karakteristik gelatin kulit kambing yang diproduksi melalui proses asam basa. J. Agritech. 31(3).

Stainsby G. (1977). The Gelatin Gel and The Sol-Gel Transformation. In : Ward.A.G.,Court, A. (ed). The Science and technology of Gelatin. NewYork: Academic Press.

Winarno, FG. (1992). Kimia Pangan dan Gizi. Jakarta: PT Gramedia Pustaka Utama.

Yang, H., Wang, Y., Zhou, P., Joe, M., Regenstein. (2008). Effects of Alkaline And Acid Pretreatment On The Physical Properties and Nanostructures of The Gelatin from Channel Catfish Skins. Journal of Food Hydrocolloids. 22 :1541-1550. 